УДК 550.4:550.43

\title{
РАДИОАКТИВНЫЕ (ТН, Ч) И РЕДКОЗЕМЕЛЬНЫЕ ЭЛЕМЕНТЫ В ПРИРОДНЫХ ВОДАХ ЦЕНТРАЛЬНОГО СИХОТЭ-АЛИНЯ (ПРИМОРСКИЙ КРАЙ)
}

\author{
Ветошкина Алена Владимировна ${ }^{1}$, \\ vetoshkina.alena@mail.ru
}

\author{
Чекрыжов Игорь Юрьевич 1 , \\ chekr2004@mail.ru
}

Паничев Александр Михайлович2, sikhote@mail.ru

\section{Вах Елена Александровна ${ }^{3}$, adasea@mail.ru}

\section{Барановская Наталья Владимировна 4 , nata@tpu.ru}

\section{Луценко Татьяна Николаевна²,} lutsenk053@bk.ru

1 Дальневосточный геологический институт ДВО РАН, Россия, 690022, г. Владивосток, пр. 100-лет Владивостоку, 159.

2 Тихоокеанский институт географии ДВО РАН, Россия, 690041, г. Владивосток, ул. Радио, 7.

${ }^{3}$ Тихоокеанский институт океанологии им. Ильичева ДВО РАН, Россия, 690041, г. Владивосток, ул. Балтийская, 43.

${ }^{4}$ Национальный исследовательский Томский политехнический университет, Россия, 634050, г. Томск, пр. Ленина, 30.

Актуальность. Сложная картина баланса Th и U, взаимосвязь их с редкоземельными элементами в природных водах различного состава и важность этих элементов как индикаторов для гидрогеохимических построений и выводов определяет актуальность их изучения в разных регионах с использованием современных аналитических методов.

Цель: рассмотреть баланс тория и урана и взаимосвязи радиоактивных и редкоземельных элементов в природных водах центрального Сихотэ-Алиня (Приморский край).

объекты: содержание и баланс урана и тория в природных водах трех районов иентрального Сихотэ-Алиня в Приморском крае: «Шандуй», «Ванчин», «Бикин».

Методы. 55 элементов определены методом масс-спектрометрии с индуктивно связанной плазмой (ICP-MS) (спектрометр Agilent 7700x, Agilent Techn., США). Вторая пробирка использовалась для определения пяти макрокатионов атомноэмиссионной спектрометрией (спектрометр іСАР 7600 Dио), а также шести анионов ионной хроматографрией (ионножидкостный хроматографь LC-20, Shimadzu, Япония).

Результаты. Приводятся новые данные по содержанию радиоактивных элементов (тория и урана), величине Th/U, содержанию РЗЭ в природных водах, приуроченных к расположению кудуров (специфических мест проявления литосрагии) в трех районах, находящихся территориально в иентральном Сихотэ-Алине Приморского края: «Шандуй», «Ванчин», «Бикин». Установлены средние содержания радиоактивных (Th, U) и редкоземельных (La, Ce, Pr, Nd, Pm, Sm, Eu, Gd, Tb, Dy, Ho, Er, Tm, Yb, Lu) элементов в природных водах. Исследуемье природные воды относятся к ультрапресным и пресным, со средней минерализацией 52,4 ме/л. Содержание U в водах колеблется от 0,005 до 1,067 мка/л. Концентрация Th в воде колеблется от 0,003 до 2,299 мка/л. Соотношение торий-уран в водах колеблется от 0,01 до 5,3. Отмечается положительная зависимость между содержанием тория в водах и количеством редкоземельных элементов в пресных водах. Спектр распределения редкоземельных элементов в природных водах, вероятно, наследуется из дренируемых цеолитизированных и оглиненных кислых пород.

\section{Ключевые слова:}

Редкоземельные и радиоактивные элементы, природные воды, солонцы, кудуры, индикаторные показатели, соотношения элементов, Приморский край, Сихотэ-Алинь.

\section{Введение}

В результате массового внедрения в аналитические работы метода масс-спектрометрии с индуктивно-связанной плазмой (ICP-MS) и других современных методов стало возможным одновременное и прецизионное определение содержания радиоактивных (уран и торий) и редкоземельных (лантаноиды и иттрий) элементов в водах. С.Л. Шварцев в своей обобщающей работе [1] привел сводные данные по абсолютным содержаниям этих элементов в воде. На основе этих данных С.И. Арбузовым и Л.П. Рихвановым [2] были рассчитаны показатели торий- 
уранового отношения как важного геохимического индикатора этих родственных химических элементов, поведение которых близко в эндогенных магматических и высокотемпературных флюидных процессах. Предполагается общая закономерность в распространении тория и урана, поскольку величина торийуранового отношения изменяется для разных образований в пределах Солнечной системы в узком интервале значений и выдерживается во многих горных породах. Однако строгое соотношение не выдерживается в динамично изменяющихся системах с участием воды. Основными параметрами, решающими в миграционном процессе, являются формы нахождения элементов и ландшафтно-геохимические условия природной среды [3]. Современные оценки растворенной части этих элементов в речных водах говорят о преобладании $\mathrm{U}$ в воде, но в то же время исследователями приводятся примеры водных источников, в которых содержание Th больше, чем U. Так, например, отношение $\mathrm{Th}$ к $\mathrm{U}(\mathrm{Th} / \mathrm{U})$ в поверхностных водах некоторых районов Сибири колеблется от 0,01 до 5,24 $[4,5]$. В терминах радиогеохимии можно сказать, что природа радиоактивности воды колеблется от урановой $(\mathrm{Th} / \mathrm{U}<1)$, смешанной торий-урановой до ториевой $(\mathrm{Th} / \mathrm{U}>5)$ [2]. В свою очередь, редкоземельные элементы (РЗЭ, в англоязычной литературе REE) также широко используются в геохимии для решения принципиальных вопросов реконструкции характера геологических процессов, источников вещества, геодинамических обстановок формирования горных пород и месторождений полезных ископаемых. Исследованные водные объекты приурочены к местам распространения литофагиальной активности диких животных - кудуров. Предполагается, что литофагиальная активность обуславливается, в том числе, и высоким содержанием РЗЭ в природных средах данных районов. Сложная картина баланса Th и U, взаимосвязь их с РЗЭ в природных водах различного состава и важность этих элементов как индикаторов для гидрогеохимических построений и выводов определяет актуальность их изучения в разных регионах с использованием современных аналитических методов.

К РЗЭ, или лантаноидам, относятся 15 элементов периодической системы химических элементов Д.И. Менделеева (лантаноиды): $\mathrm{La}, \mathrm{Ce}, \mathrm{Pr}, \mathrm{Nd}, \mathrm{Pm}, \mathrm{Sm}, \mathrm{Eu}$, Gd, Dy, Ho, Tb, Er, Tm, Yb, Lu, а также Y и Sc. В данной статье мы используем деление лантаноидов на две подгруппы: легкие (LREE) - La, Ce, Pr, Nd, Pm, $\mathrm{Sm}, \mathrm{Eu}$, и тяжелые (HREE) - Gd, Tb, Dy, Ho, Er, Tm, $\mathrm{Yb}, \mathrm{Lu}[6]$. Так как ранее при анализе сумм Р3Э в водах Y и Sc не учитывались, мы также их не брали в расчет, чтобы полученные данные можно было сопоставлять с данными предшественников. Также из списка изученных лантаноидов исключен $\mathrm{Pm}$, как практически не встречающийся в природе и не определяемый стандартными методами элемент.

Цель настоящих исследований: рассмотреть баланс тория и урана и взаимосвязи радиоактивных и редкоземельных элементов в природных водах центрального Сихотэ-Алиня (Приморский край).

\section{Краткая характеристика исследованных районов}

В настоящей статье рассматривается содержание РЗЭ и баланс урана и тория в природных водах трех районов центрального Сихотэ-Алиня на территории Приморского края (рис. 1).

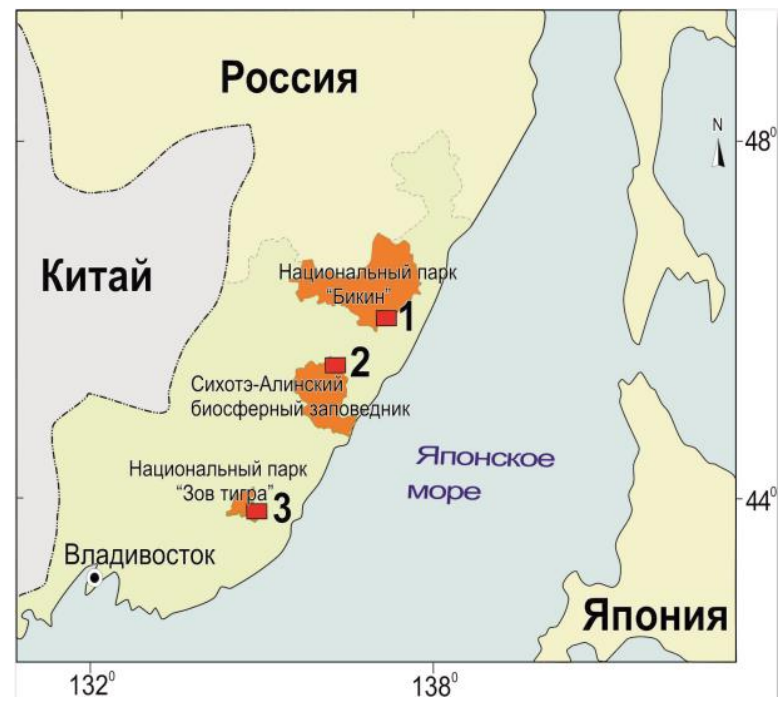

Pис. 1. Местоположение районов исследования: 1 - «Бикин»; 2 - «Шандуй»; 3 - «Ванчин»

Fig. 1. Location of study areas: $1-«$ Bikin»; $2-«$ Shanduy»; $3-«$ Vanchin»

Выбор для исследований именно этих районов был обусловлен наличием на их территории многочисленных природных солонцов - кудуров, поскольку работы проводились в рамках междисциплинарного проекта РНФ «Влияние литолого-геохимической специфики горных ландшафтов Сибири и Дальнего Востока на формирование элементного состава организма млекопитающих». Кудуры - это геологоландшафтные комплексы, которые регулярно посещают дикие животные с целью употребления горных пород и минерализованных родниковых вод; следовательно, кудуриты - это литогенные вещества, потребляемые животными на кудурах [7]. Исследования последних лет показали, что районы, где распространены кудуры, представляют собой ландшафтные редкоземельные аномалии, как правило, связанные с метасоматически измененными и оглиненными кислыми кайнозойскими вулканитами и минерализованными водами $[8,9]$.

Первый исследованный район (далее по тексту район «Бикин») находится на водоразделе между верховьями рек Бикин и Максимовка, в юго-восточной части национального парка Бикин, в пределах Верхнебикинской палеовулканоструктуры, сложенной преимущественно кислыми вулканитами верхнемелового и раннекайнозойского возраста. В меньшей степени на площади участка распространены среднекайнозойские вулканиты контрастной серии, а также вулканогенно-осадочные и осадочные слабоугленосные отложения. На площади участка отмечены отдельные проявления золота, олова и полиметаллов. 
Второй район (далее по тексту - район «Шандуй») расположен в центральной части хребта СихотэАлинь, на северо-восточной части территории Сихотэ-Алинского государственного биосферного заповедника, и включает г. Солонцовая (Шандуй), верховья р. Заболоченной и правых притоков р. Таежной. Гора Солонцовая и ее окрестности являются руинами палеоценового Солонцовского (Шандуйского) палеовулкана и сложены кислыми и средними вулканитами с резким преобладанием их пирокластических разновидностей. Рудная минерализация представлена проявлениями золота и серебра [10].

Третий район исследований (далее - район «Ванчин») находится в южной части горного хребта Сихотэ-Алинь, на территории национального парка «Зов тигра», и охватывает бассейн верховьев р. Милоградовка (Ванчин). Большая часть исследованного района находится в пределах р. Угольного (правый приток Милоградовки), дренирующего отложения Ванчинской вулкано-тектонической угленосной впадины. Впадина образовалась в раннем кайнозое и заполнена вулканогенно-осадочными и терригенными отложениями преимущественно палеоценового и эоценового возраста с маломощными пластами бурых углей. В северо-восточной части к впадине подступает среднегорье с отметками до 1305 м (г. Фасольная), сложенное преимущественно верхнемеловыми и раннекайнозойскими вулканитами. Характерной особенностью этого района является наличие многочисленных рудопроявлений золота, серебра, олова, полиметаллов, а также германиевой и уникальной редкоземельной минерализации в углях $[11,12]$.

\section{Материалы и методы}

Материалы для исследований были получены в рамках полевых работ в июле и сентябре 2020 г. Всего в трех исследованных районах было отобрано 123 пробы воды из местных водотоков и родников, в том числе на источниках, приуроченных к природным солонцам - кудурам. Вода отбиралась в полиэтиленовые емкости 250 мл, которые во время полевых работ (не более 5 суток) хранились в автомобильном холодильнике. Подготовка проб воды к анализам выполнялась в лаборатории геохимии Тихоокеанского института географии ДВО РАН. В нефильтрованной пробе измерялась электропроводность и выполнялись определения $\mathrm{pH}$ и общей щелочности, предполагалось, что она обусловлена присутствием $\mathrm{HCO}_{3}^{-}$. Каждая проба фильтровалась через мембранный фильтр $(0,45$ микрон) с помощью вакуумного насоса и разливалась в две пробирки (полипропилен) емкостью 50 мл. Далее пробы воды, разлитые на две одинаковые пробирки, направлялись в Аналитический центр коллективного пользования при Дальневосточном геологическом институте ДВО РАН. Одна из пробирок после подкисления воды особо чистой азотной кислотой шла на определение (состава) концентраций 55 элементов методом масспектрометрии с индуктивно связанной плазмой (ИСП-МС) (спектрометр Agilent 7700x, Agilent Techn., США). Вторая пробирка шла на определение пяти макрокатионов методом атомно- эмиссионной спектрометрии (спектрометр іСАР 7600 Duo), а также шести анионов методом ионной хроматографии (ионный жидкостный хроматограф LC-20, Shimadzu, Япония). Общая минерализация воды $\left(\sum \mathrm{n}\right)$ определялась как сумма макрокомпонентов: $\sum \mathrm{n}=\left[\mathrm{Na}^{+}\right]+\left[\mathrm{K}^{+}\right]+\left[\mathrm{Ca}^{2+}\right]+\left[\mathrm{Mg}^{2+}\right]+\left[\mathrm{Si}^{4+}\right]+\left[\mathrm{SO}_{4}{ }^{2}\right]+[\mathrm{Cl}]+\left[\mathrm{HCO}_{3}\right]$. Содержание растворенного органического углерода выполняли из фильтрованной пробы на анализаторе TOCvcpn (Shimadzu) методом термокаталитического окисления.

Для интерпретации и анализа данных проводился стандартный анализ среднестатистических параметров с использованием программы Excel, SigmaPlot 12.0. Для построения диаграммы Пайпера использовалась программа AquaChem 5.1.

Для выявления индикаторных показателей использовались соотношения элементов: Th/U, LREE/HREE, a также сумма редкоземельных элементов: $\sum \mathrm{P} 33=\mathrm{La}+\mathrm{Ce}+\mathrm{Pr}+\mathrm{Nd}+\mathrm{Sm}+\mathrm{Eu}+\mathrm{Gd}+$

$\mathrm{Dy}+\mathrm{Ho}+\mathrm{Tb}+\mathrm{Er}+\mathrm{Yb}+\mathrm{Lu}$.

При интерпретации геохимических исследований широко распространено нормирование содержаний РЗЭ к их содержанию в эталонных образцах с целью определения процессов фракционирования элементов в различных физико-химических условиях [13]. В настоящих исследованиях содержание РЗЭ мы нормировали на североамериканский сланец (NASC) $[14,15]$

\section{Результаты и обсуждение}

Все изученные водотоки в трех районах являются ультрапресными и пресными с минерализацией не более 280 мг/л, преимущественно ультрапресными со средней минерализацией 52,4 мг/л. Содержание РЗЭ имеет в водах большую вариабельность - так, сумма всех РЗЭ в воде изменяется от 0,033 до 31,33 мкг/л. Содержание U в водах колеблется от минимального значения 0,005 , достигая максимального 1,067 мкг/л. Концентрация Th в воде также имеет широкий разброс значений от 0,003 до 2,299 мкг/л. Торийурановое отношение в водах изменяется в пределах от 0,01 до 5,3 (табл. 1). Рассмотрим изменение содержания компонентов более подробно по районам исследования.

Поверхностные воды района «Бикин» гидрокарбонатные, по катионному составу преобладают натриево-магниево-кальциевые (рис. 2). Воды преимущественно ультрапресные, пресные с максимальной минерализацией до 278 мг/л. По показателю $\mathrm{pH}$ воды от нейтральных до слабощелочных: 6,45-7,9.

Содержание урана в природных водах района «Бикин» изменяется от 0,006 до 0,336 мкг/л при его среднем содержании 0,059 мкг/л (табл. 1). Содержание тория колеблется от 0,003 до 0,416 мкг/л, средняя концентрация составляет 0,032 мкг/л. $\mathrm{Th} / \mathrm{U}$ изменяется от 0,01 , достигая максимального значения 4,6 , в среднем составляет 0,7. Изменение концентрации тория в воде заметно коррелирует (коэффициент корреляции Пирсона 0,7) с распределением редкоземельных элементов в воде. 
Таблица 1. Распространенность РЗЭ и радиоактивных элементов (урана и тория) в природных водах исследованных районов [17]

Table 1. Abundance of REE and radioactive elements (uranium and thorium) in natural waters of the studied areas [17]

\begin{tabular}{|c|c|c|c|c|c|c|c|c|c|}
\hline \multirow{2}{*}{$\begin{array}{c}\text { Район } \\
\text { исследования } \\
\text { Research area }\end{array}$} & \multirow[t]{2}{*}{$\mathrm{pH}$} & \multirow[t]{2}{*}{$\begin{array}{c}\text { Параметры } \\
\text { Parametres }\end{array}$} & \multirow{2}{*}{$\begin{array}{c}\text { Минерализация, } \\
\text { мг/л } \\
\text { Mineralization, mg/l }\end{array}$} & \multirow{2}{*}{$\begin{array}{c}\text { Сумма РЗЭ, } \\
\text { мкг/л } \\
\text { REE amount, } \mu \mathrm{g} / 1\end{array}$} & LREE & HREE & Th & $\mathrm{U}$ & \multirow[t]{2}{*}{$\mathrm{Th} / \mathrm{U}$} \\
\hline & & & & & \multicolumn{2}{|c|}{$\%$} & \multicolumn{2}{|c|}{ мкг/л/ $/ \mathrm{g} / 1$} & \\
\hline \multirow{5}{*}{ 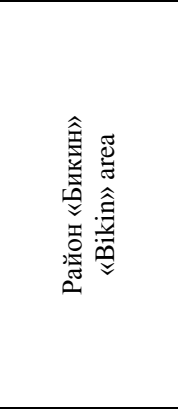 } & \multirow{5}{*}{$6,45-7,9$} & $\begin{array}{l}\text { минимум } \\
\text { minimum }\end{array}$ & 32,2 & 0,03 & 66 & 14 & 0,003 & 0,006 & 0,01 \\
\hline & & $\begin{array}{l}\text { максимум } \\
\text { maximum }\end{array}$ & 278,5 & 6,73 & 86 & 35 & 0,416 & 0,336 & 4,6 \\
\hline & & $\begin{array}{l}\text { среднее } \\
\text { mean }\end{array}$ & 80,7 & 0,67 & 75 & 25 & 0,032 & 0,059 & 0,7 \\
\hline & & $\begin{array}{c}\text { медиана } \\
\text { median }\end{array}$ & 65,7 & 0,35 & 74 & 26 & 0,015 & 0,038 & 0,4 \\
\hline & & $\begin{array}{c}\text { число проб } \\
\text { number of } \\
\text { samples } \\
\end{array}$ & 43 & 43 & 43 & 43 & 43 & 43 & 43 \\
\hline \multirow{5}{*}{ 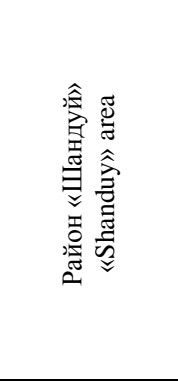 } & \multirow{5}{*}{$6,0-7,46$} & $\begin{array}{l}\text { минимум } \\
\text { minimum }\end{array}$ & 20,8 & 0,20 & 57 & 9 & 0,006 & 0,018 & 0,2 \\
\hline & & $\begin{array}{l}\text { максимум } \\
\text { maximum }\end{array}$ & 65,1 & 96,73 & 91 & 43 & 10,01 & 1,738 & 5,8 \\
\hline & & $\begin{array}{c}\text { среднее } \\
\text { mean }\end{array}$ & 38,8 & 5,49 & 72 & 28 & 0,534 & 0,214 & 1,0 \\
\hline & & $\begin{array}{c}\text { медиана } \\
\text { median }\end{array}$ & 37,4 & 0,81 & 73 & 27 & 0,03 & 0,060 & 0,7 \\
\hline & & $\begin{array}{c}\text { число проб } \\
\text { number of } \\
\text { samples }\end{array}$ & 24 & 24 & 24 & 24 & 24 & 24 & 24 \\
\hline \multirow{5}{*}{ 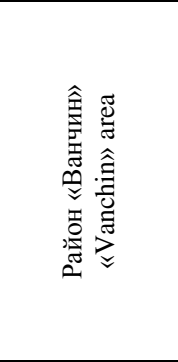 } & \multirow{5}{*}{$3,5-7,0$} & $\begin{array}{l}\text { минимум } \\
\text { minimum }\end{array}$ & 6,0 & 0,08 & 66 & 13 & 0,004 & 0,005 & 0,3 \\
\hline & & $\begin{array}{l}\text { максимум } \\
\text { maximum }\end{array}$ & 134,6 & 31,33 & 87 & 34 & 2,299 & 0,720 & 5,4 \\
\hline & & $\begin{array}{l}\text { среднее } \\
\text { mean }\end{array}$ & 36,2 & 2,97 & 78 & 22 & 0,201 & 0,086 & 2,1 \\
\hline & & $\begin{array}{c}\text { медиана } \\
\text { median }\end{array}$ & 31,5 & 1,45 & 78 & 22 & 0,083 & 0,035 & 2,2 \\
\hline & & $\begin{array}{c}\text { число проб } \\
\text { number of } \\
\text { samples }\end{array}$ & 56 & 56 & 56 & 56 & 56 & 56 & 56 \\
\hline
\end{tabular}

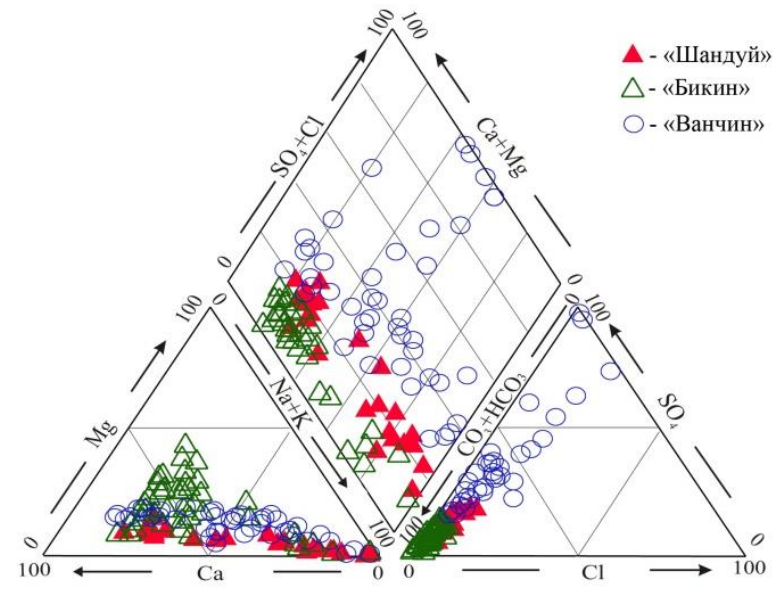

Pис. 2. Диаграмма Пайпера для вод обследованных районов, по [16] с дополнениями

Fig. 2. Piper diagram for the waters of the surveyed areas [16]

В целом в водах района исследований «Бикин» содержание урана в природных водах выше, чем содержание тория. Максимальные $\mathrm{Th} / \mathrm{U}$ отношения отмечены в водах: левого притока руч. Буреломный $(4,5)$; устья р. Лосевка и устья 5-го сверху ключа справа по p. Пещерка $(2,2)$; устья 3-го левого ключа сверху по р. Правая Пещерка $(1,6)$; устьев руч. Солонцовый и Староверский, ручья на солонце Неожиданный $(1,2)$; правого притока руч. Староверский $(1,01)$; ручья на солонце Директорский $(1,0)$.

В спектрах распределения РЗЭ для исследованного района «Бикин» отсутствует четкая дифференциация между обогащением легкими и тяжелыми РЗЭ (рис. 3). Сумма РЗЭ в водах района «Бикин» изменяется от 0,003 до 6,73 мкг/л при среднем значении 0,67 мкг/л, медианное значение составляет 0,5 мкг/л (табл. 1). На долю LREE приходится в среднем $75 \%$, на HREE - 25 \%. Для слабощелочных вод района исследований характерны спектры распределения РЗЭ как с сильно («Б-19» - ручей Правая Лосевка, верховья и «Б-2» из ключа, приток р. Правая Пещерка с минимальными содержаниями РЗЭ), так и со слабовыраженным Еu максимумом и Се минимумом. Максимальные значения РЗЭ для проб района исследований «Бикин» содержатся в пробах «Б-17» (ручей на солонце Неожиданный) и «Б-20» (левый приток руч. Директорский), спектры имеют картину распределения РЗЭ с выраженными Еu и Се минимумами. 
Поверхностные воды района исследований «Шандуй» также ультрапресные, значения минерализации изменяются от 20,8 до 65,1 мг/л; по показателю $\mathrm{pH}$ воды нейтральные: $\mathrm{pH}$ от 6,00 до 7,46. По макрокомпонентному составу воды натриево-кальциевые гидрокарбонатные, но также встречаются чисто натриевые воды (рис. 2). Содержание урана в природных водах района «Шандуй» изменяется от 0,018 до 1,738 мкг/л при его среднем содержании 0,214 мкг/л. Содержание тория колеблется от 0,0065 до 10,01 мкг/л, средняя концентрация составляет 0,534 мкг/л. Торий-урановое отношение в водах изменяется от 0,2 до 5,8 при среднем значении отношения 1,0. Так же как в водах района «Бикин» здесь прослеживается весьма высокая корреляция между содержанием тория и РЗЭ в воде (коэффициент корреляции Пирсона 0,96) (рис. 4).

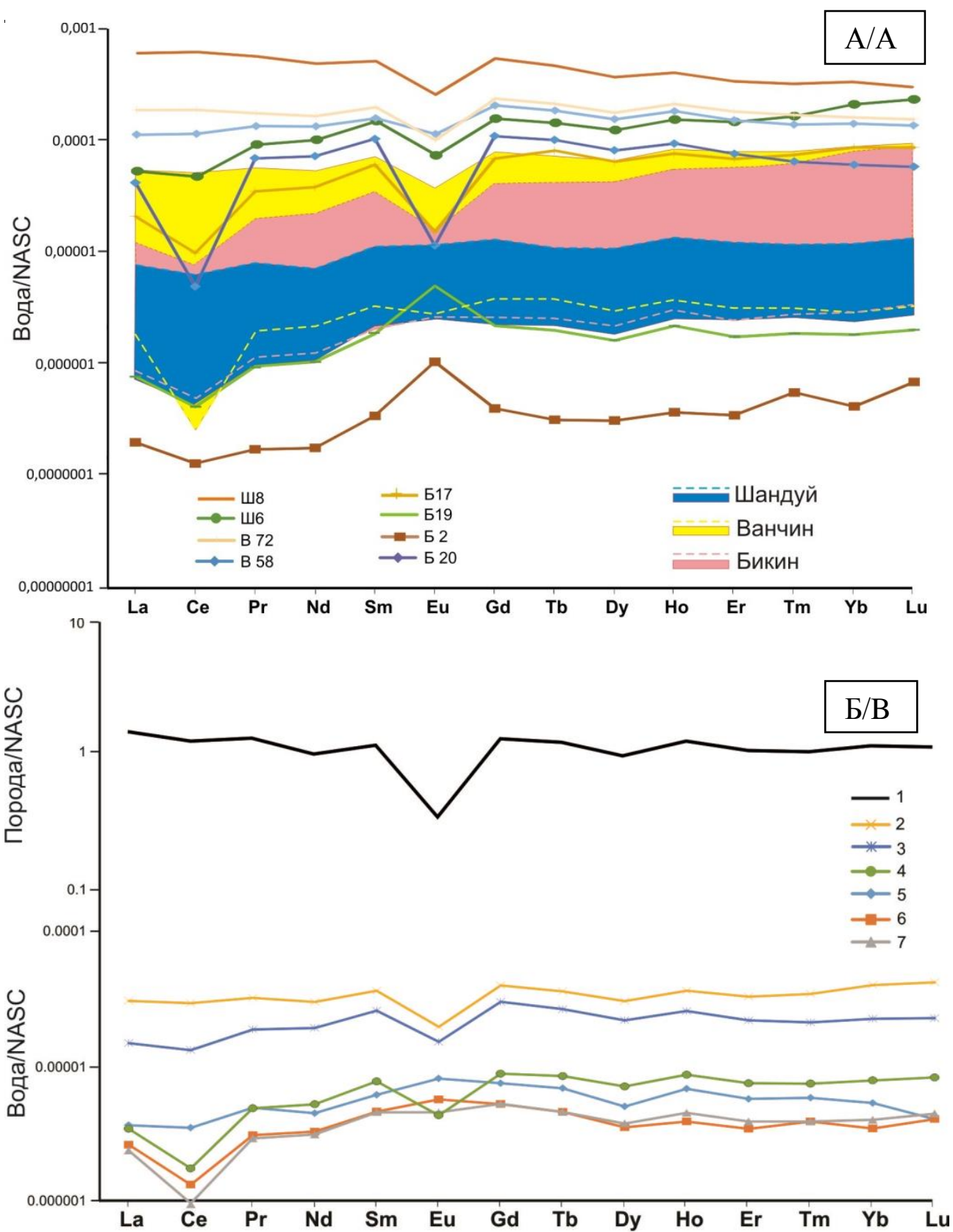

Pис. 3. А) спектры распределения РЗЭ в водах исследованных районов; Б) профили распределения средних кониентраций NASC-нормированных Р3Э (по [15]) в водных пробах и пробах туфов исследованных районов в сравнении со средними показателями рек мира (по [18]), рек Приморского края (по [19]) и восточного макросклона Сихотэ-Алиня (по [19]). 1 - порода; средние содержания в пробах водыл: 2 - «Шандуй», 3 - «Ванчин», 4 - «Бикин», 5 - по миру, 6 - по Приморскому краю, 7 - по Восточному макросклону Сихотэ-Алиня

Fig. 3. A) spectra of REE distribution in the waters of the studied areas; B) profiles of distribution of average concentrations of NASC-normalized REE [15] in water samples of the studied regions in comparison with the average indicators of the world's rivers ([18]), rivers of Primorsky Krai (according to [19]) and the eastern macroslope of the Sikhote-Alin ( [19]). 1 - rock; average contents in water samples: 2 - "Shanduy», 3 - "Vanchin», 4 - «Bikin», 5 - the world, 6 - the Primorsky Krai, 7 - the Eastern Macroslope of Sikhote-Alin 


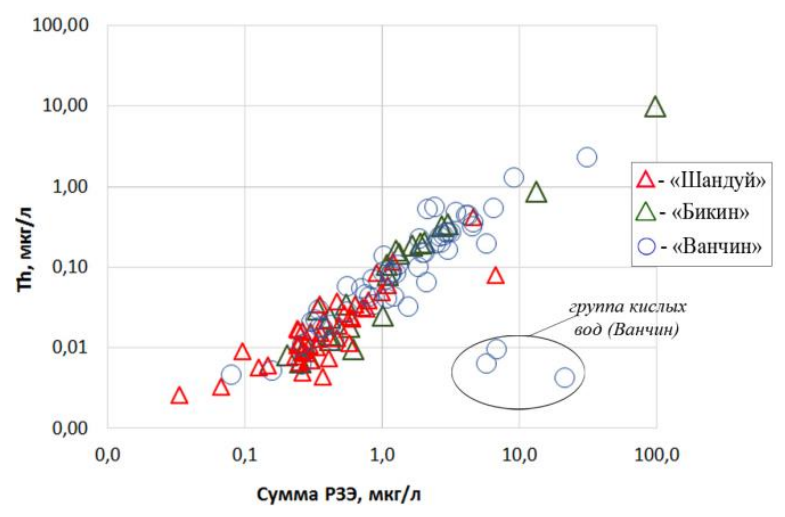

Рис. 4. Зависимость распределения тория от суммы РЗЭ в водах исследованных районов

Fig. 4. Dependence of thorium distribution on REE amount in the waters of the studied areas

Спектры распределения РЗЭ для исследованного района «Шандуй» для большинства проб идентичны (рис. 3). Кривые распределения характеризуются выраженными Еu и Се минимумами и обогащены тяжелой группой РЗЭ. В водах района «Шандуй» сумма Р3Э изменяется от 0,20 до 96,73 мкг/л при среднем значении 5,49 мкг/л, медианное значение составляет 0,81 мкг/л. На долю LREE приходится в среднем $72 \%$, на HREE - 28 \%. Однако на величину среднего содержания РЗЭ в воде оказывают очень большое влияние две пробы воды с аномальным содержанием РЗЭ - 96,73 мкг/л, в ней же фиксируется максимальное значение тория для данного района исследований 10,01 мкг/л, в другой пробе с аномально высокими значениями сумма РЗЭ составляет 13,25 мкг/л, но в ней концентрация тория составляет 0,86 мкг/л, что находится в пределах медианного значения для района исследований. В пробе с максимальным значением суммы РЗЭ (Ш 8) - на графике самый верхний спектр, отсутствует Се минимум и преобладает обогащение легкими РЗЭ. Исходя из того, что в этой же пробе очень высокое торий-урановое отношение - 5,8, и самое высокое содержание растворенного органического углерода, можно предположить, что высокое содержание РЗЭ связано с их присутствием в составе ассоциатов высокомолекулярных органических веществ либо с органоминеральными коллоидами (рис. 5) [20].

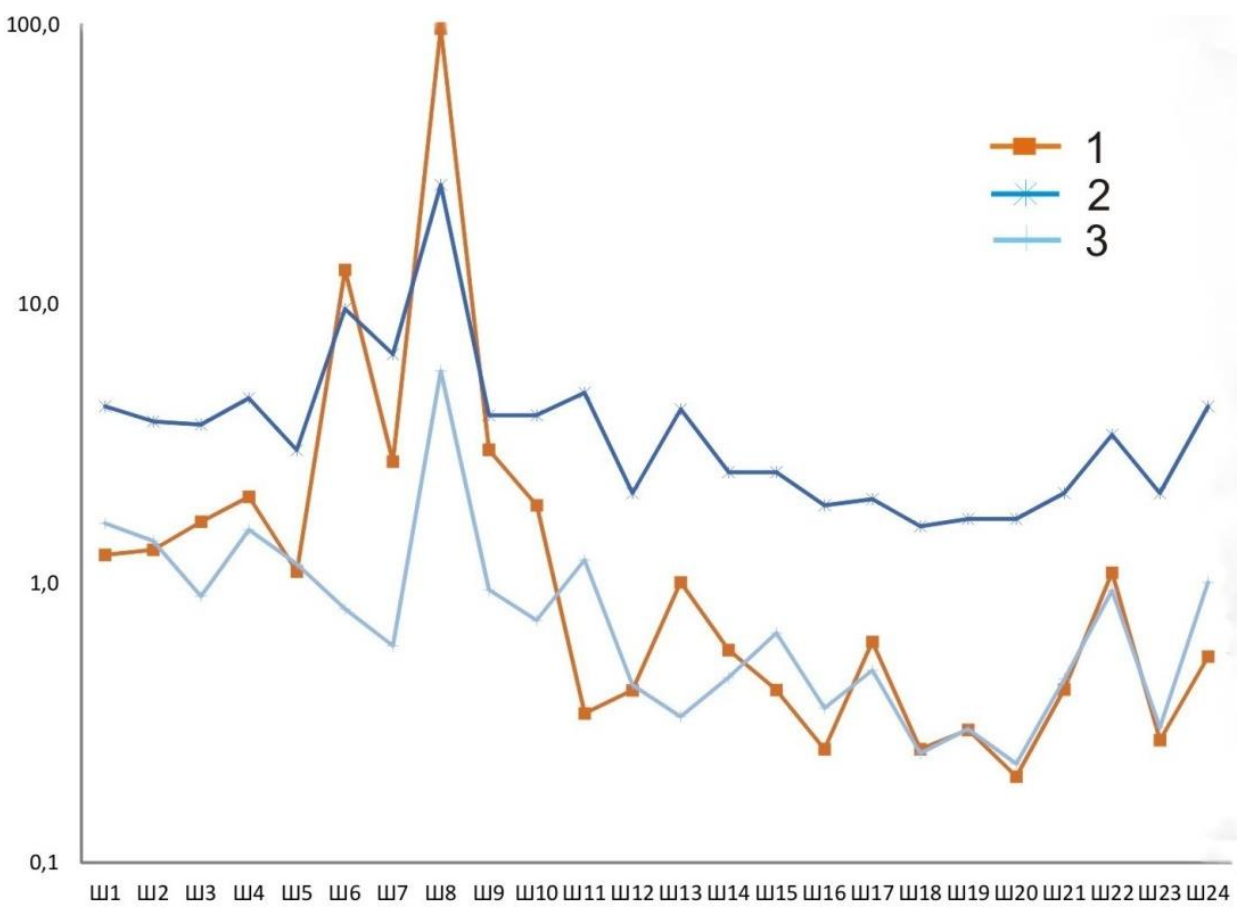

Рис. 5. Распределение растворенного органического углерода, суммы редкоземельных элементов и TH/U в природных водах района «Шандуй»: 1 - сумма РЗЭ; 2 - РОУ; 3 - Th/U

Fig. 5. Distribution of dissolved organic carbon, the amount of REE and Th/U in the natural waters of the «Shanduy» region: 1 - REE amount; 2 - DOC; $3-T h / U$

Растворенный органический углерод играет важную роль при фракционировании РЗЭ [20]. По положительной корреляция $\mathrm{POY,} \mathrm{Th/U} \mathrm{и} \mathrm{суммы} \mathrm{РЗЭ} \mathrm{в}$ пробах, максимально обогащенных РЗЭ, можно предположить, что торий и РЗЭ связаны высокомолекулярными фульвокислотными соединениями [20, 21]. В то же время в ряде проб (на фоне низкого торийуранового отношения) наблюдается высокое содержание суммы РЗЭ и РОУ. Так, в пробе с аномальным содержанием РЗЭ (Ш 6) в спектре присутствует Еu минимум и прослеживается обогащение преимущественно тяжелой группой РЗЭ, торий-урановое отношение близко к медианному значению и составляет 0,8. Для проб, обогащенных РЗЭ, так же как и в обогащенных Р3Э пробах района «Бикин», в спектрах распределения РЗЭ характерен Еи минимум, видимо, наследуемый из вмещающих пород со взвесью. В пробах бедных РЗЭ спектры распределения РЗЭ 
имеют похожий характер как для поверхностных вод Восточного макросклона Сихотэ-Алиня (рис. 3) [19].

Поверхностные воды третьего района исследований «Ванчин» являются ультрапресными с минерализацией до 134 мг/л. Воды гидрокарбонатно-натриевокальциевые с присутствием сульфат- и хлорид-ионов. Воды обследованного района кислые и нейтральные (pH от 3,5 до 7,0). Большинство вод слабокислые с $\mathrm{pH}$ 5,4-6,4, что характерно для малых водотоков лесной зоны. Группа кислых источников (3 пробы), скорее всего, приурочена к зоне окисления сульфидных руд и расположена локально. Для этих вод характерно преобладание сульфат-ионов, повышенных концентраций $\mathrm{Al}, \mathrm{Fe}, \mathrm{Mn}, \mathrm{Zn}, \mathrm{Co}, \mathrm{Ni}, \mathrm{Be}, \mathrm{Ge}, \mathrm{Rb}, \mathrm{Y}, \mathrm{Sc}, \mathrm{Tl}$ и Р3Э [19]. Для водотоков Ванчинской впадины характерно преобладание тория в воде над ураном. В целом по массиву проанализированных проб (56 проб) среднее значение торий-уранового отношения составляет 2,1 и колеблется от 0,2 до 5,4 (табл. 1). Содержание урана в природных водах района «Ванчин» варьирует от 0,005 до 0,720 мкг/л при его среднем содержании 0,086 мкг/л. Содержание тория колеблется от 0,004 до 2,298 мкг/л при среднем значении 0,201 мкг/л.

Установлено, что содержание тория и урана в водах района «Ванчин» с различной кислотностью различается. Все пробы воды района «Ванчин» были поделены на три группы: слабокислые с рН 5,4-6,0; нейтральные с $\mathrm{pH}$ 6,5-7,0 и кислые с $\mathrm{pH}$ 3,5-3,9. Большая часть проб относится к группе со слабокис- лым показателем $\mathrm{pH}$. В этой группе проб отчетливо прослеживается преобладание тория в воде в три и более раза, чем урана. Так, содержание урана в природных водах района «Ванчин» со слабокислым значением рН изменяется от 0,006 до 0,720 мкг/л при его среднем содержании 0,089 мкг/л. Содержание тория колеблется от 0,021 до 2,299 мкг/л, средняя концентрация составляет 0,252 мкг/л. Ториево-урановое отношение варьирует от 0,9 до 5,23, среднее значение составляет 3,0 (табл. 2). Содержание урана в нейтральных природных водах района Ванчинской впадины изменяется от 0,005 до 0,236 мкг/л при его среднем содержании 0,071 мкг/л. Содержание тория колеблется от 0,005 до 0,516 мкг/л, средняя концентрация составляет 0,123 мкг/л. Торий-урановое отношение варьирует от 0,2 до 5,0, среднее значение составляет 1,3 (табл. 2). С уменьшением $\mathrm{pH}$ урана в воде становится больше, чем тория (табл. 2). Таким образом, в группе кислых источников, расположенных в зоне окисления сульфидных руд, содержание урана составляет от 0,012 до 0,026 мкг/л при его среднем содержании 0,017 мкг/л. Содержание тория изменяется от 0,004 до 0,010 мкг/л, средняя концентрация составляет 0,007 мкг/л. Торий-урановое отношение варьирует от 0,2 до 0,7 , среднее значение составляет 0,5 . Несмотря на высокое содержание редкоземельных элементов в данной группе источников, концентрации урана и тория значительно ниже, чем в водах других групп Ванчинской впадины.

Таблица 2. Распространенность урана и тория в природных водах в зависимости от рН на примере Ванчинской виадины [17]

Table 2. Abundance of uranium and thorium in natural waters depending on $p H$ by the example of the Vanchin depression [17]

\begin{tabular}{|c|c|c|c|c|c|c|c|c|c|}
\hline \multirow{2}{*}{\begin{tabular}{c|} 
Тип вод \\
Water type \\
\end{tabular}} & \multirow{2}{*}{$\mathrm{pH}$} & \multirow{2}{*}{$\begin{array}{c}\text { Параметры } \\
\text { Parametres } \\
\end{array}$} & \multirow{2}{*}{\begin{tabular}{|c} 
Минерализация, мг/л \\
Mineralization, mg/l
\end{tabular}} & \multirow{2}{*}{$\begin{array}{l}\text { Сумма РЗЭ, мкг/л } \\
\text { REE amount, } \mu \mathrm{g} / \mathrm{l} \\
\end{array}$} & LREE & HREE & $\mathrm{Th}$ & $\mathrm{U}$ & \multirow{2}{*}{$\mathrm{Th} / \mathrm{U}$} \\
\hline & & & & & \multicolumn{2}{|c|}{$\%$} & \multicolumn{2}{|c|}{ 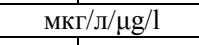 } & \\
\hline \multirow{5}{*}{ 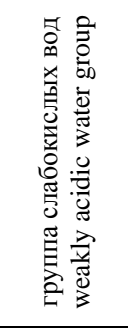 } & \multirow{5}{*}{$5,4-6,5$} & $\begin{array}{l}\text { минимум } \\
\text { minimum }\end{array}$ & 6,0 & 0,31 & 0,021 & 0,006 & 0,9 & 0,0056 & 0,9262 \\
\hline & & $\begin{array}{c}\text { максимум } \\
\text { maximum }\end{array}$ & 134,6 & 31,33 & 2,299 & 0,720 & 5,3 & 0,7195 & 5,2453 \\
\hline & & $\begin{array}{c}\text { среднее } \\
\text { mean }\end{array}$ & 30,8 & 3,11 & 0,252 & 0,089 & 3,0 & 0,0894 & 3,0428 \\
\hline & & $\begin{array}{c}\text { медиана } \\
\text { median }\end{array}$ & 26,5 & 1,98 & 0,147 & 0,041 & 3,3 & 0,0407 & 3,2651 \\
\hline & & \begin{tabular}{|c|} 
число проб \\
number of samples \\
\end{tabular} & 37 & 37 & 37 & 37 & 37 & 37 & 37 \\
\hline \multirow{5}{*}{ 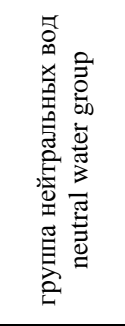 } & \multirow{5}{*}{$6,5-7,0$} & $\begin{array}{l}\text { минимум } \\
\text { minimum }\end{array}$ & 15,4 & 0,08 & 0,005 & 0,005 & 0,2 & 0,0053 & 0,2278 \\
\hline & & $\begin{array}{c}\text { максимум } \\
\text { maximum }\end{array}$ & 71,9 & 4,11 & 0,516 & 0,236 & 5,0 & 0,2359 & 4,9780 \\
\hline & & $\begin{array}{c}\text { среднее } \\
\text { mean }\end{array}$ & 47,1 & 1,08 & 0,123 & 0,071 & 1,3 & 0,0709 & 1,3287 \\
\hline & & $\begin{array}{c}\text { медиана } \\
\text { median }\end{array}$ & 46,2 & 0,43 & 0,018 & 0,024 & 0,9 & 0,0241 & 0,8461 \\
\hline & & $\begin{array}{c}\text { число проб } \\
\text { number of samples } \\
\end{array}$ & 15 & 15 & 15 & 15 & 15 & 15 & 15 \\
\hline \multirow{5}{*}{ 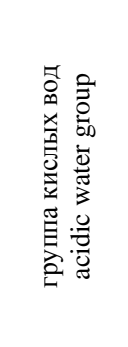 } & \multirow{5}{*}{$3,5-3,9$} & $\begin{array}{l}\text { минимум } \\
\text { minimum }\end{array}$ & 42,8 & 5,78 & 0,004 & 0,012 & 0,2 & 0,0117 & 0,1620 \\
\hline & & $\begin{array}{l}\text { максимум } \\
\text { maximum }\end{array}$ & 67,8 & 21,57 & 0,010 & 0,026 & 0,7 & 0,0259 & 0,6688 \\
\hline & & $\begin{array}{c}\text { среднее } \\
\text { mean }\end{array}$ & 52,3 & 11,39 & 0,007 & 0,017 & 0,5 & 0,0172 & 0,4558 \\
\hline & & $\begin{array}{c}\text { медиана } \\
\text { median }\end{array}$ & 46,3 & 6,84 & 0,006 & 0,014 & 0,5 & 0,0141 & 0,5366 \\
\hline & & $\begin{array}{c}\text { число проб } \\
\text { number of samples }\end{array}$ & 3 & 3 & 3 & 3 & 3 & 3 & 3 \\
\hline
\end{tabular}


Положительная зависимость между содержанием в водах тория и количеством РЗЭ, обусловленная геохимическим сродством этих элементов [22], отмечаемая в двух предыдущих районах, также характерна и для слабокислых и нейтральных вод Ванчинской впадины, коэффициент корреляции Пирсона составляет 0,7, что оценивается как высокий, согласно шкале Чеддока (рис. 3).

По опубликованным данным содержание в речных водах составляет для урана - 0,4-0,5 мкг/л [4, 11, 22], для тория - 0,1 мкг/л [23]. Торий-урановое отношение при этом близко к среднему значению для осадочных горных пород и на треть ниже среднего для земной коры. При низкой растворимости тория в водах этот факт говорит о том, что значительная доля урана и особенно тория в поверхностных водах мигрирует в составе коллоидов.

Спектры распределения РЗЭ для исследованного района «Ванчин» имеют картину распределения РЗЭ c Eu и Се минимумами, на спектрах прослеживается некоторое обогащение средней группой РЗЭ (рис. 3). Аномально высокие содержания РЗЭ отмечены среди гидрокарбонатных вод в пробе «В-72», среди сульфатных кислых вод в пробе «В-59» (Малый ручей с болота (сульфидная зона)). В пробе «В-59» при сумме Р3Э 21,57 мкг/л Th/U равно 0,2. В пробе «В-72» сумма РЗЭ составляет 31,33 мкг/л и содержание тория имеет свое максимальное значение для района исследований «Ванчин» 2,298 мкг/л, и как следствие $\mathrm{Th} / \mathrm{U}$ тоже имеет высокое значение и равно 3,2.

На спектрах распределения РЗЭ по всем исследованным районам (рис. 8) мы видим, что спектры имеют по усредненным величинам похожую картину распределения с выраженными Еu и Се минимумами и имеют спектр, характерный в целом для Восточного макросклона Сихотэ-Алиня [19]. В то же время для спектров распределения РЗЭ характерен более выраженный Eu минимум, что наследуется из пород. На диаграмме приведен спектр распределения РЗЭ в туфах района «Ванчин».

Отношения валовых содержаний урана к торию $(\mathrm{Th} / \mathrm{U})$ являются важным показателем как в прикладном, так и в теоретическом аспекте. Этот показатель, по результатам исследований ряда авторов [24-29], является чрезвычайно важным индикатором. Th/U отношение, начиная от Солнечной системы в целом $(\mathrm{Th} / \mathrm{U}=3,72)$ до ее планет и Луны $(\mathrm{Th} / \mathrm{U}=3,55)$, метеоритов $(\mathrm{Th} / \mathrm{U}=2,5-8,6)$, магматических образований различного типа, находится в чрезвычайно узком интервале величин (2,5-5 при преобладании 3,5-4,5) [25, 29], что заставляет предполагать существование общей закономерности в распространении тория и урана. Эта система отношений выдерживается во многих горных породах за исключением химических и биогенных образований, продуктов метаморфизма и метасоматизма, т. е. достаточно динамичных природных систем с участием воды [25].

Из рис. 6 видно, что воды исследованного района «Шандуй» лежат в диапазоне торий-уранового отношения от $\mathrm{Th} / \mathrm{U}=0,5$ до $\mathrm{Th} / \mathrm{U}=2$. Для природных вод «Бикина» показана широкая вариабельность торий- уранового отношения. Большая часть исследованных проб природных вод в районе «Бикин» имеет значение $\mathrm{Th} / \mathrm{U}<1$. Что касается исследованных проб природных вод района «Ванчин», то на рисунке они лежат в диапазоне $1>\mathrm{Th} / \mathrm{U}<5$, в отдельных пробах имея значение $\mathrm{Th} / \mathrm{U}>5$.

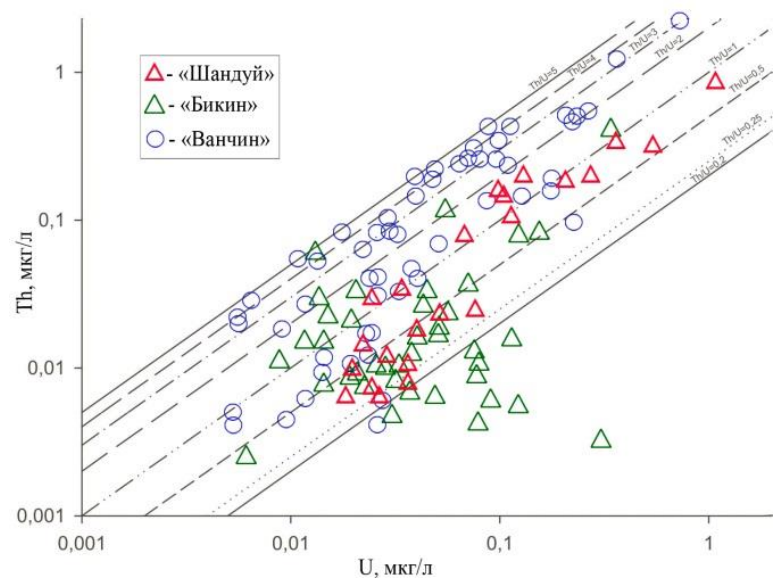

Рис. 6. Радиогеохимическая характеристика природных вод изученных районов

Fig. 6. Radiogeochemical characteristics of natural waters of the studied areas

Распределение соотношения радиоактивных и суммы редкоземельных элементов (рис. 7) показало их однородное расположение в системе «Th-U-SP3Э». Из общей картины выделяется ряд проб района «Бикин», обедненных РЗЭ и торием.

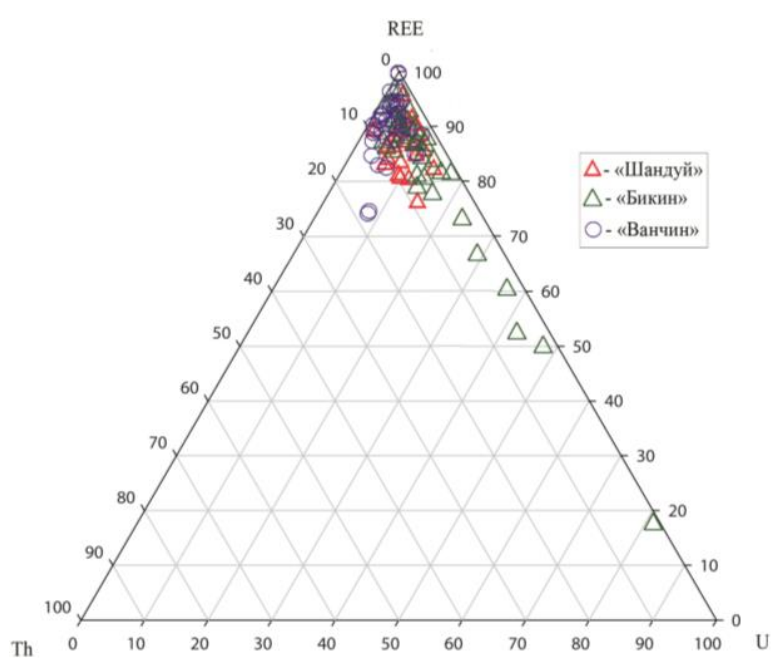

Рис. 7. Тройная диаграмма соотношения содержаний Th, U исуммь РЗЭ в природных водах исследованных районов

Fig. 7. Ternary diagram of Th, $U$ contents, sum of REE in the natural waters of the surveyed areas

В изученных районах максимально обогащены РЗЭ отдельные пробы как кислых, так и нейтральных источниковых вод. Для немногочисленных кислых проб характерно низкое торий-урановое соотношение и отрицательная корреляция тория и РЗЭ. Для аномальных по содержанию суммы РЗЭ отдельных 
нейтральных вод, отобранных в непосредственной близости от солонцов - кудуров, характерно высокое торий урановое отношение и отчетливый европиевый минимум на спектре распределения РЗЭ.

\section{Заключение}

Были изучены содержания радиоактивных (Th, U) и редкоземельных элементов ( $\mathrm{La}, \mathrm{Ce}, \mathrm{Pr}, \mathrm{Nd}, \mathrm{Pm}, \mathrm{Sm}$, $\mathrm{Eu}, \mathrm{Gd}, \mathrm{Tb}, \mathrm{Dy}, \mathrm{Ho}, \mathrm{Er}, \mathrm{Tm}, \mathrm{Yb}, \mathrm{Lu})$ в природных водах, приуроченных к районам развития кудуров, расположенных в Центральном Сихотэ-Алине Приморского края.

Проведенный анализ распространенности урана и тория и РЗЭ в природных водах центрального Сихотэ-Алиня показал широкую вариабельность в их распределении. Высокий коэффициент корреляции малорастворимого тория и РЗЭ в обогащенных ими пресных водах, вероятно, свидетельствует о миграции последних преимущественно в составе коллоидов в таких источниках, к которым часто приурочены природные солонцы - кудуры, где и отмечаются прояв-

\section{СПИСОК ЛИТЕРАТУРЫ}

1. Шварцев С.Л. Гидрогеохимия зоны гипергенеза. - М.: Недра, 1998. $-380 \mathrm{c}$

2. Арбузов С.И., Рихванов Л.П. Геохимия радиоактивных элементов. - Томск: Изд-во Томского политехнического университета, 2020. - 341 с

3. Regional geochemical survey of concealed sandstone-type uranium deposits using fine-grained soil and groundwater in the Erlian basin, north-east China / B. Zhang, X. Wang, J. Zhou, Z. Han, Q. Liu, W. Wang, R. Li, B. Zhang, B. Dou // Journal of Geochemical Exploration. - 2020. - V. 216. - 106573. URL: https://doi.org/10.1016/j.gexplo.2020.106573 (дата обращения 01.11.2021).

4. Уран и торий в природных водах юго-востока Алтае-Саянской области / Ю.Г. Копылова, Н.В. Гусева, К.Д. Аракчаа, А.А. Хващевская, И.С. Мазурова, О.Д. Аюнова, Ч.К Ойдуп., К.М. Рычкова // Радиоактивность и радиоактивные элементы в среде обитания человека: Материалы V Международной конференции. - Томск, 2016. - С. 339-345.

5. Распределение урана и тория в природных и техногенных водах (напримере объектов Западной и Восточной Сибири) И.Н. Мягкая, Б.Ю. Сарыг-оол, И.С. Кириченко, В.И. Малов, М.А. Густайтис, Е.В. Лазарева // Радиоактивность и радиоактивные элементы в среде обитания человека. - Томск: Изд-во Томского политехнического университета, 2021. - С. 385-389.

6. Protano G., Riccobono F. High contents of rare earth elements (REEs) in stream waters of a $\mathrm{Cu}-\mathrm{Pb}-\mathrm{Zn}$ mining area // Environmental Pollution. - 2002. - V. 117. - P. 499-514.

7. Geophagy in animals and geology of kudurs (mineral licks): a review of Russian publications / A.M. Panichev, K.S. Golokhvast, A.N. Gulkov, I.Yu. Chekryzhov // Environmental Geochemistry and Health. - 2013. - V. 35. - № 1. - P. 133-152.

8. Rare earth elements upon assessment of reasons of the geophagy in Sikhote-Alin region (Russian Federation), Africa and other world regions / A.M. Panichev, V.K. Popov, I.Yu. Chekryzhov, I.V. Seryodkin, T.A. Stolyarova, S.V. Zakusin, A.A. Sergievich, P.P. Khoroshikh // Environmental Geochemistry and Health. 2016. - V. 38. - № 6. - P. 1255-1270.

9. Results of geological and geochemical investigations of Kaplanov kudurs in Sikhote-Alin, Russian Far East / A.M. Panichev, I.V. Seryodkin, O.Yu. Zaumyslova, E.A. Wach, T.A. Stolyarova, A.A. Sergievich, V.K. Popov, I.Yu. Chekryzhov, M.G. Blokhin, P.P. Khoroshikh // Arabian Journal of Geosciences. - 2018. V. 11 (17): 493. DOI: 10.1007/s12517-018-3820-z

10. Ветренников В.В. Геологическое строение Сихотэ-Алинского заповедника и Центрального Сихотэ-Алиня // Тр. СихотэАлинского заповедника. - 1976. - Вып. 6. - 167 с. ления процессов литофагии, детально описанных нами ранее. Это определяется, видимо, как миграционными особенностями элементов в условиях гипергенеза, так и процессами перераспределения тория и урана в воде и донных отложениях таких источников, претерпевающих периодическое «взмучивание» тонких минеральных фракций в процессе литофагиальной активности диких животных. Для спектров распределения Р3Э характерен более выраженный $\mathrm{Eu}$ минимум, чем характерный в целом для Восточного макросклона Сихотэ-Алиня, который, вероятно, наследуется из дренируемых цеолитизированных и оглиненных кислых пород. Отмеченная положительная корреляция растворенного органического углерода, Th/U и суммы Р3Э и связываемая нами с наличием коллоидов в изученных пробах требует дальнейшего изучения.

Работа выполнена при финансовой поддержке грантов РНФ: № 20-67-47005, 20-64-47021.

11. Середин В.В., Чекрыжов И.Ю. Рудоносность Ванчинского грабена // Геология рудных месторождений. - 2011. - Т. 53. № 3. - C. 230-249.

12. Новые данные по стратиграфии, вулканизму и цеолитовой минерализации Ванчинской впадины, Приморский край / И.Ю. Чекрыжов, В.К. Попов, А.М. Паничев, В.В. Середин, Е.В. Смирнова // Тихоокеанская геология. - 2010. - Т. 29. № 4. - C. 45-63.

13. The European shale: an improved data set for normalisation of rare earth element and yttrium concentrations in environmental and biological samples from Europe / M. Bau, K. Schmidt, A. Pack, V. Bendel, D. Kraemer // Applied Geochemistry. - 2018. - V. 90. P. 142-149.

14. Migaszewskia Z.M., Gałuszkaa A. The characteristics, occurrence, and geochemical behavior of rare earth elements in the environment: a review // Critical Reviews in Environmental Science and Technology. - 2015. - V. 45. - Iss. 5. - P. 429-471.

15. The North American shale composite: its compilation, major and trace element characteristics / L.P. Gromet, R.F. Dymek, L.A. Haskin, R.L. Korotev // Geochimica et Cosmochimica Acta. - 1984. - V. 48. - Iss. 12. - P. 2469-2482.

16. Landscape REE anomalies and the cause of geophagy in wild animals at kudurs (mineral salt licks) in the Sikhote-Alin (Primorsky Krai, Russia) / A.M. Panichev, N.V. Baranovskaya, I.V. Seryodkin, I.Yu. Chekryzhov, E.A. Vakh, B.R. Soktoev, A.I. Belyanovskaya, R.A. Makarevich, T.N. Lutsenko, N.Yu. Popov, A.V. Ruslan, D.S. Ostapenko, A.V. Vetoshkina, V.V. Aramilev, A.S. Kholodov, K.S. Golokhvast // Environmental Geochemistry and Health. - 2021. URL: https://doi.org/10.1007/ s10653-021-01014-w (дата обращения 01.11.2021).

17. Уран и торий в природных водах центрального Сихотэ-Алиня (Приморский край) / А.В. Ветошкина, И.Ю. Чекрыжов, А.М. Паничев, Е.А. Вах // Радиоактивность и радиоактивные элементы в среде обитания человека. - Томск: Изд-во Томского политехнического университета, 2021. - С. 109-114.

18. Gaillardet J., Viers J., Dupre B. Trace elements in river waters // Treatise on Geochemistry. - 2003. - V. 5. - P. 225-272.

19. Вах Е.А. Геохимия редкоземельных элементов в природных и техногенных водах юга Дальнего Востока России. - Владивосток: Дальневосточный федеральный университет, 2014. $168 \mathrm{c}$.

20. Торопов А.С., Солдатова Е.А., Рихванов Л.П. Формы миграции радионуклидов (U и $\mathrm{Th})$ в природных водах в различных геохимических условиях на основе расчетных и экспериментальных данных // Известия ТПУ. Инжиниринг георесурсов. 2020. - T. 331. - № 12. - С. 7-21.

21. Геохимические особенности поведения редкоземельных элементов в водах Дальнего Востока России в условиях природ- 
ных и антропогенных аномалий / О.В. Чудаев, Н.А. Харитонова, Г.А. Челноков, И.В. Брагин, Е.Г. Калитина. - Владивосток: Дальнаука, 2017. - 152 с.

22. Иванов В.В. Экологическая геохимия элементов. Кн. 6. Редкие f-элементы. - М.: Экология, 1997. - 607 с.

23. Корж В.Д. Геохимия элементного состава гидросферы. - М.: Наука, 1991. - 243 с.

24. Рихванов Л.П. Радиогеохимическая типизация рудномагматических образований. - Новосибирск: Гео, 2003. $536 \mathrm{c}$.

25. Рихванов Л.П. Радиоактивные элементы в геосферных оболочках // Радиоактивность и радиоактивные элементы в среде обитания человека. - Томск: Тандем-Арт, 2004. - С. 498-505.

26. Смыслов А.А. Уран и торий в земной коре. - Л: Недра, 1974. $231 \mathrm{c}$
27. Allegre C.V., Dupre B., Lewin E. Torium/uranium ratio of the Earth // Chemical Geology. - 1986. - V. 56. - № 3-4. - P. 219-227.

28. Барановская Н.В. Тенденции накопления некоторых актинидов в живом веществе // Радиоактивность и радиоактивные элементы в среде обитания человека. - Томск: STT, 2016. C. 93-98.

29. Редкоземельные и радиоактивные $(\mathrm{Th}, \mathrm{U})$ элементы в компонентах природной среды на территории Томской области / Н.В. Барановская, Е.Н. Агеева, Б.Р. Соктоев, Д.В. Наркович, О.А. Денисова, Т.В. Матковская // Известия Томского политехнического университета. Инжиниринг георесурсов. 2020. - T. 331. - № 2. - C. 17-28.

Поступила 08.12.2021 2.

\section{Информация об авторах}

Bетошкина A.B., младший научный сотрудник лаборатории геохимии, Дальневосточный геологический институт ДВО РАН.

Чекрыжюв И.Ю., научный сотрудник лаборатории геохимии, Дальневосточный геологический институт ДВО РАН.

Паничев А.М., доктор биологических наук, ведущий научный сотрудник лаборатории экологии и охраны животных, Тихоокеанский институт географии ДВО РАН.

$\boldsymbol{B a x} \boldsymbol{E} . \boldsymbol{A}$., кандидат геолого-минералогических наук, научный сотрудник лаборатории гидрохими, Тихоокеанский институт океанологии им. Ильичева ДВО РАН.

Барановская Н.B., доктор биологических наук, профессор отделения геологии Инженерной школы природных ресурсов, Национальный исследовательский Томский политехнический университет.

Луценко Т.Н., кандидат географических наук, научный сотрудник лаборатории геохимии, Тихоокеанский институт географии ДВО РАН. 
UDC 550.4:550.43

\title{
RADIOACTIVE (TH, U) AND RARE EARTH ELEMENTS IN NATURAL WATERS OF CENTRAL SIKHOTE-ALIN (PRIMORSKY KRAI)
}

\author{
Alena V. Vetoshkina ${ }^{1}$, \\ vetoshkina.alena@mail.ru \\ Igor Yu. Chekryzhov 1 , \\ chekr2004@mail.ru
}

Alexander M. Panichev², sikhote@mail.ru

Elena A. Vakh ${ }^{3}$ adasea@mail.ru

Natalia V. Baranovskaya ${ }^{4}$, nata@tpu.ru

\section{Tatyana N. Lutsenko²,} lutsenk053@bk.ru

1 Far East Geological Institute FEBRAS,

159, 100 let Vladivostoku avenue, Vladivostok, 690022, Russia.

2 Pacific Institute of Geography FEBRAS,

7, Radio street, Vladivostok, 690041, Russia.

3 V.I. llichev Pacific Oceanological Institute FEBRAS,

43, Baltiyskaya street, Vladivostok, 690041, Russia.

4 National Research Tomsk Polytechnic University, 30, Lenin avenue, Tomsk, 634050, Russia.

Relevance. The complex picture of Th and $U$ balance, their relationship with rare earth elements in natural waters of various compositions and the importance of these elements as indicators for hydrogeochemical constructions and conclusions determines the relevance of their study in different regions using modern analytical methods.

Objects: content and balance of uranium and thorium in natural waters of three regions of the central Sikhote-Alin in the Primorsky Krai: "Shanduy», «Vanchin», «Bikin».

Methods. 55 elements were detected by inductively coupled plasma mass spectrometry (ICP-MS) (spectrometer Agilent 7700x, Agilent Techn., USA). The second tube was used to determine five macrocations by atomic emission spectrometry (iCAP 7600 Duo spectrometer), as well as six anions by ion chromatography (ion liquid chromatograph LC-20, Shimadzu, Japan).

Results. New data are presented on the content of radioactive elements (thorium and uranium), the value of Th/U, the content of rare earth elements in natural waters confined to the location of the kudurs (specific places of manifestation of lithophagy) in three regions geographically located in the central Sikhote-Alin of the Primorsky Krai: «Shanduy», "Vanchin», «Bikin». The average contents of radioactive (Th, U) and rare earth ( $\mathrm{La}, \mathrm{Ce}, \mathrm{Pr}, \mathrm{Nd}, \mathrm{Pm}, \mathrm{Sm}, \mathrm{Eu}, \mathrm{Gd}, \mathrm{Tb}, \mathrm{Dy}, \mathrm{Ho}, \mathrm{Er}, \mathrm{Tm}, \mathrm{Yb}, \mathrm{Lu}$ ) elements in natural waters were established. The studied natural waters are ultrafresh and fresh with an average mineralization of 52,4 mg/l. U content in waters ranges from 0,005 to $1,067 \mu \mathrm{g} / \mathrm{l}$. Th concentration in water varies from 0,003 to $2,299 \mu \mathrm{g} / \mathrm{l}$. The thorium-uranium ratio in waters varies from 0,01 to 5,3 . A positive relationship was found between the content of thorium in the waters and the amount of rare earth elements.

Key words:

Rare earth and radioactive elements, natural waters, salt licks, kudurs, indicator values, ratios of elements, Primorsky Krai, Sikhote-Alin.

The research was financially supported by the RSF grants: no. 20-67-47005, 20-64-47021.

\section{REFERENCES}

1. Shvartsev S.L. Gidrogeokhimiya zony gipergeneza [Hydrogeochemistry of the hypergenesis zone]. Moscow, Nedra Publ., 1998. $380 \mathrm{p}$

2. Arbuzov S.I., Rikhvanov L.P. Geokhimiya radioaktivnykh elementov [Geochemistry of radioactive elements]. Tomsk, Tomsk Polytechnic University Publ., 2020. 341 p.

3. Zhang B., Wang X., Zhou J., Han Z., Liu Q., Wang W., Li R., Zhang B., Dou B. Regional geochemical survey of concealed sandstone-type uranium deposits using fine-grained soil and groundwater in the Erlian basin, north-east China. Journal of Geochemical Exploration,
2020, vol. 216, 106573. Available at: https://doi.org/10.1016/j.gexplo. 2020.106573 (accessed 1 November 2021).

4. Kopylova Yu.G., Guseva N.V., Arakchaa K.D., Khvashchevskaya A.A., Mazurova I.S., Ayunova O.D., Oydup Ch.K., Rychkova K.M. Uran i toriy v prirodnykh vodakh yugo-vostoka Altae-Sayanskoy oblasti [Uranium and thorium in natural waters of the southeast of the Altai-Sayan region]. Materialy V Mezhdunarodnoy konferentsii. Radioaktivnost $i$ radioaktivnye elementy $v$ srede obitaniya cheloveka [Materials of the V International Conference. Radioactivity and Radioactive Elements in the Human Environment]. Tomsk, 2016. pp. 339-345. 
5. Myagkaya I.N., Saryg-ool B.Yu., Kirichenko I.S., Malov V.I., Gustaitis M.A., Lazareva E.V. Raspredelenie urana i toriya v prirodnykh i tekhnogennykh vodakh (naprimere obektov Zapadnoy i Vostochnoy Sibiri) [Distribution of uranium and thorium in natural and technogenic waters (for example objects of Western and Eastern Siberia)]. Radioaktivnost $i$ radioaktivnye elementy $v$ srede obitaniya cheloveka [Radioactivity and radioactive elements in environment]. Tomsk, Tomsk Polytechnic University Publ., 2021. pp. 385-389.

6. Protano G., Riccobono F. High contents of rare earth elements (REEs) in stream waters of a $\mathrm{Cu}-\mathrm{Pb}-\mathrm{Zn}$ mining area. Environmental Pollution, 2002, vol. 117, pp. 499-514.

7. Panichev A.M., Golokhvast K.S., Gulkov A.N., Chekryzhov I.Yu. Geophagy in animals and geology of kudurs (mineral licks): a review of Russian publications. Environmental Geochemistry and Health, 2013, vol. 35, no. 1, pp. 133-152.

8. Panichev A.M., Popov V.K., Chekryzhov I.Yu., Seredkin I.V., Stolyarova T.A., Zakusin S.V., Sergievich A.A., Khoroshikh P.P. Rare earth elements upon assessment of reasons of the geophagy in Sikhote-Alin region (Russian Federation), Africa and other world regions. Environmental Geochemistry and Health, 2016, vol. 38, no. 6, pp. 1255-1270.

9. Panichev A.M., Seryodkin I.V., Zaumyslova O.Yu., Wach E.A., Stolyarova T.A., Sergievich A.A., Popov V.K., Chekryzhov I.Yu., Blokhin M.G., Khoroshikh P.P. Results of geological and geochemical investigations of Kaplanov kudurs in Sikhote-Alin, Russian Far East. Arabian Journal of Geosciences, 2018, vol. 11 (17): 493. DOI: 10.1007/s12517-018-3820-z

10. Vetrennikov V.V. Geologicheskoe stroenie Sikhote-Alinskogo gosudarstvennogo zapovednika i tsentralnogo Sikhote-Alinya [Geological structure of the Sikhote-Alin nature reserve and Central Sikhote-Alin]. Trudy Sikhote-Alinskogo zapovednika, 1976 no. 6, pp. 167.

11. Seredin V.V., Chekryzhov I.Yu. Ore content of the Vanchinsky graben. Geology of Ore deposits, 2011, vol. 53, no. 3, pp. 230-249. In Rus.

12. Chekryzhov I.Yu., Popov V.K., Panichev A.M., Seredin V.V., Smirnova E.V. New data on stratigraphy, volcanism and zeolite mineralization of the Vanchinsky depression, Primorsky Territory. Russian Journal of Pacific Geology, 2010, vol. 29, no. 4, pp. 45-63. In Rus.

13. Bau M., Schmidt K., Pack A., Bendel V., Kraemer D. The European shale: an improved data set for normalisation of rare earth element and yttrium concentrations in environmental and biological samples from Europe. Applied Geochemistry, 2018, vol. 90, pp. 142-149.

14. Migaszewskia Z.M., Gałuszkaa A. The characteristics, occurrence, and geochemical behavior of rare earth elements in the environment: a review. Critical Reviews in Environmental Science and Technology, 2015, vol. 45, Iss. 5, pp. 429-471.

15. Gromet L.P., Dymek R.F., Haskin L.A., Korotev R.L. The «North American shale composite»: its compilation, major and trace element characteristics. Geochimica et Cosmochimica Acta, 1984, vol. 48, pp. 2469-2482.

16. Panichev A.M., Baranovskaya N.V., Seryodkin I.V., Chekryzhov I.Yu., Vakh E.A., Soktoev B.R., Belyanovskaya A.I., Makarevich R.A., Lutsenko T.N., Popov N.Yu., Ruslan A.V., Ostapenko D.S., Vetoshkina A.V., Aramilev V.V., Kholodov A.S., Golokhvast K.S. Landscape REE anomalies and the cause of geophagy in wild animals at kudurs (mineral salt licks) in the Sikhote-Alin (Pri- morsky Krai, Russia). Environmental Geochemistry and Health, 2021. Available at: https://doi.org/10.1007/s10653-02101014-w (accessed 1 November 2021).

17. Vetoshkina A.V., Chekryzhov I.Yu., Panichev A.M., Vakh E.A. Uran i toriy v prirodnykh vodakh tsentralnogo Sikhote-Alinya (Primorskiy kray) [Uranium and thorium in natural waters of the central Sikhote-Alin (Primorsky Territory)]. Radioaktivnost i radioaktivnye elementy $v$ srede obitaniya cheloveka [Radioactivity and radioactive elements in environment]. Tomsk, Tomsk Polytechnic University Publ., 2021. pp. 109-114.

18. Gaillardet J., Viers J., Dupre B. Trace elements in river waters. Treatise on geochemistry, 2003, vol. 5, pp. 225-272.

19. Vakh E.A. Geokhimiya redkozemelnykh elementov $v$ prirodnykh $i$ tekhnogennykh vodakh yuga Dalnego Vostoka Rossii [Geochemistry of rare earth elements in natural and technogenic waters in the south of the Russian Far East.]. Vladivostok, FEFU Publ., 2014. $168 \mathrm{p}$.

20. Toropov A.S., Soldatova E.A., Rikhvanov L.P. Forms of migration of radionuclides ( $\mathrm{U}$ and $\mathrm{Th})$ in natural waters under various geochemical conditions based on calculated and experimental data. Bulletin of the Tomsk Polytechnic University. Geo Assets Engineering, 2020, vol. 331, no. 12, pp. 7-21. In Rus.

21. Chudaev O.V., Kharitonova N.A., Chelnokov G.A., Bragin I.V., Kalitina E.G. Geokhimicheskie osobennosti povedeniya redkozemelnykh elementov $v$ vodakh Dalnego Vostoka Rossii v usloviyakh prirodnykh $i$ antropogennykh anomaliy [Geochemical features of the behavior of rare earth elements in the waters of the Russian Far East under natural and anthropogenic anomalies]. Vladivostok, Dalnauka Publ., 2017. 152 p.

22. Ivanov V.V. Ekologicheskava geokhimiva elementov. Kn. 6. Redkie f-elementy [Ecological geochemistry of elements. B. 6. Rare f-elements]. Moscow, Ekologiya Publ., 1997. 607 p.

23. Korzh V.D. Geokhimiya elementnogo sostava gidrosfery [Geochemistry of the elemental composition of the hydrosphere]. Moscow, Nauka Publ., 1991. 243 p.

24. Rikhvanov L.P. Radiogeokhimicheskaya tipizatsiya rudnomagmaticheskikh obrazovaniy [Radiogeochemical typification of ore-magmatic formation]. Novosibirsk, Geo Publ., 2003. 536 p.

25. Rikhvanov L.P. Radioaktivnye elementy $\mathrm{v}$ geosfernykh obolochkakh [Radioactive elements in geospheric envelopes]. $\mathrm{Ra}$ dioaktivnost i radioaktivnye elementy $v$ srede obitaniya cheloveka [Radioactivity and radioactive elements in environment]. Tomsk, Tandem-Art Publ., 2004. pp. 498-505.

26. Smyslov A.A. Uran i toriy v zemnoy kore [Uranium and thorium in the earth's crust]. Lenigrad, Nedra Publ., 1974. 231 p.

27. Allegre C.V., Dupre B., Lewin E. Torium/uranium ratio of the Earth. Chemical Geology, 1986, vol. 56, no. 3-4, pp. 219-227.

28. Baranovskaya N.V. Tendentsii nakopleniya nekotorykh aktinidov $\mathrm{v}$ zhivom veshchestve [Accumulation trends of some actinides in living matter]. Radioaktivnost $i$ radioaktivnye elementy $v$ srede obitaniya cheloveka [Radioactivity and radioactive elements in environment]. Tomsk, STT Publ., 2016. pp. 93-98.

29. Baranovskaya N.V., Ageeva E.V., Soktoev B.R., Narkovich D.V., Denisova O.A., Matkovskaya T.V. Rare earth and radioactive (Th, U) elements in the components of the natural environment in the Tomsk region. Bulletin of the Tomsk Polytechnic University. Geo Assets Engineering, 2020, vol. 331, no. 2, pp. 17-28. In Rus.

Received: 8 December 2021.

\section{Information about the authors}

Alena V. Vetoshkina, junior researcher, Far East Geological Institute FEBRAS.

Igor Yu. Chekryzhov, researcher, Far East Geological Institute FEBRAS.

Alexander M. Panichev, Dr. Sc., leading researcher, Pacific Institute of Geography FEBRAS.

Elena A. Vakh, Cand. Sc., researcher, V.I. Ilichev Pacific Oceanological Institute FEBRAS.

Natalia V. Baranovskaya, Dr. Sc., professor, National Research Tomsk Polytechnic University.

Tatyana N. Lutsenko, Cand. Sc., researcher, Pacific Institute of Geography FEBRAS. 